\title{
The political awareness of the Stock Market Regulation
}

\author{
Yu Liao \\ City College of Wuhan University of Science and Technology, Wuhan, 430083, China. \\ tomliao-898@163.com
}

Keywords: The Stock Market Disaster, Stock Market Regulation, Political awareness, Strategy.

\begin{abstract}
With the rapid development of Chinese stock market and the innovation of financial tools, In recent years, In recent years, Investors' enthusiasm cause the volatility of the stock price in the stock market. In the last year, there appeared tumbling three times in a row in the Shanghai and Shenzhen stock market, It caused huge losses to investors. This article analysis the background of "political awareness ", discussed the strategy of the "political awareness" in the Stock Market Regulation.
\end{abstract}

\section{Introduction}

The stock market is already issued the place of the shares transfer, trade and circulation , also known as the secondary market [1].

The stock market has important position in national economy, its first function is the optimal allocation of resources, it is completed mainly in the primary market by way of an IPO. Listed company can raise money and be recognized by the market because that it can provide the products and services by the cognition of the investors, and it can produce the tight and profitable products that meet the need of social demand; secondly, the function to refinance in the secondary market. sustainable financing function of listed companies, is the embodiment of the function of the social resources configuration of course, relocation is also leaning to the high quality of the listed company; Thirdly, the price of the shares in the secondary market are related with the information of he stability of the social politics, economic situation , it plays the function of vane and barometer; fourthly, its value found function enables people to make rational judgment for the future of the enterprise; finally, the most important distinction is the function of value-added between the stock market and the casino, it makes investors learn judgment and analysis, and make rational investors.

\section{The meaning of "political awareness"}

The political is the direct strategy, means and organizational forms which the political classes maintain and develop their class interests and deal with the internal relationship and the relationship with other class, ethnic and national . In 1997, the main content of the party spirit and party spirit education that the three emphases education: to stress theoretical study, political awareness and good conduct is put forward in the political report to the XV congress of CCP[2]. "political awareness" is considered to be the core of the three emphases education.

The connotation of the "political awareness" is rich, including political orientation, political standpoint, political view, political discipline, political discrimination and political acumen. Simply a word, the "political awareness" is: to always keep a clear political mind, has a strong political position and strong party spirit, adhere to the party's principles, adhere to strict political discipline. 


\section{Why the "political awareness" is put forward in the stock market regulation}

\subsection{The 21st century, the world's financial landscape}

In the past ten years of this century, fundamental changes have taken place in the world's financial structure, the whole world the biggest change is the economic financialization. global financial landscape change has ten characteristics: the first is the global economic and financial integration; the second is the comprehensive global excess liquidity; three is economic financialization and capitalization; the fourth is the direct financing; fifth, financial derivatives rapid growth; the sixth, hedge funds, private equity funds and sovereign wealth funds has become a market main body; the seventh, the structural change of international capital flows; the eighth, the dollar and the United States to become super financial hegemony; ninth, wealth is highly concentrated; the tenth is the imbalances of the global economic and financial to be continue. these new global financial landscape cause the imbalances of today's global economic and financial that we see[3].

\subsection{The "currency war" from The United States in the financial sector}

According to the comprehensive analysis from American officials and the media data information, the implementation of an all hegemony in The United States since 2000, the goal is above the other countries in each area and air, sea and land, psychological, biochemical, network , and prepare for war with China in 2020. With the RMB to replace the dollar, a currency war is the biggest battlefield between China and the United States.

On December 10th, 2006, the "currency war" of Mr Song sales breakthrough in 100000 is still in short supply, the emergence of the "currency war" brought huge profits to the publishing world, but also gives a reminder of the masses and government administrators that should pay attention to our financial security, this is the battlefield not to be smoking. the term "currency war" is known by the masses since it.

Essentially currency war is who is in the hands of huge international financial wealth influence the economic and political using their possession of wealth, make large financial turmoil in a country or a number of countries around, or create a new monetary system, and then acquire wealth through this turmoil or system[4]. they master the country's political fate through the control of a country's economic lifeline, they induced by fomenting political event, economic crisis, control flow and distribution of the world's wealth.

Meeting held in Shangri-la in 2014 the President Mr Obama had said: "China has 1.3 billion people, the more they will rise, we would have no rice to eat, because the earth's resources supply there is a cap. So, in order to our living to be continue now, we must restrain the development of China." , there are three big weapon which America cut wool in the world is dollars, gold, foreign exchange, the stock market is another. Since the financial crisis in 2008, the economy of America is always wandering in the edge of recession, and after the second half of 2010, the risk of a global currency war is increasingly. five years later, currency war is happening imperceptibly. China's currency war with the United States is beginning from the appreciation of the RMB, In short, the idea of the United States is: the appreciation of the RMB $\rightarrow$ hot money inflow $\rightarrow$ inflation $\rightarrow$ asset bubbles $\rightarrow$ withdraw money to put bubble burst $\rightarrow$ to let the RMB system collapse, through the pressure of RMB appreciation, the effect that the United States use violent means such as the war to meet can be achieved. 


\section{The performance of the "currency war"}

In the $1990 \mathrm{~s}$, under the influence of "currency war" from the United States, Japan was forced to adopt the policy of the appreciation of the yen by a two-step process: the first step is from 1982 to 1988, the second step is from 1990 to 1995. In a decade, the yen against the dollar by 263:1 up to $95: 1$, the range of the appreciation is more than $60 \%$. It makes the deflation of Japanese economy in the decades and has brought fatal impact on Japan's economy.

Over the past 2015 years, the "currency war" has been carried out between China and the United States, it continues in 2016. first of all, the White House and the Treasury Department officials repeatedly claimed that opportunity which the RMB joins the international monetary fund (IMF) official reserve currency basket is not mature in 2015 years; second, some experts found the figure of the United States in the China's stock market plunged event in the summer of 2015; finally, the fed chairman Yellen repeatedly hinted to adjust monetary policy in 2015, almost to zero interest rates. this kind of "verbal intervention" will also impact on investors and Chinese capital outflows. there is a lot of initiative in the United States are indirect hit RMB, produced a series of unfavorable to the influence of China. Which is specifically pointed out that the United States advocate and has reached the trans-pacific partnership agreement, the agreement is intended to limit or stop China into Japan, and other series of Pacific markets. In the second half of last year, the hedge funds mainly from the United States heavily shorted the RMB, they began to evacuate after we hit back using of foreign exchange reserves. according to Reuters, last year, there are three types of hedge funds were betting heavily on the substantial depreciation of the RMB in China, two types of them have to withdraw from this kind of betting, with only a few very bearish "black swans" hedge funds are still holding long-term bet[5].

\section{Three times "crash" in Shanghai and Shenzhen stock Market in 2015}

The "currency war" has continued to expand in the broad front in 2015, According to the reference news network reported on December 16, 2015: today, Russian media said, dozens of countries involved in the currency war in the world. they reduced lower their currencies exchange rate, while increasing protests to their trading partners and competitors with similar behavior, and from a certain moment, the United States is no longer just a bystander in another nation's currency war[6]. here, I mainly discuss the "currency war" at the beginning of 2015 to 2016, and three times "crash" in Shanghai and Shenzhen stock market.

The three times "crash" brought huge disaster to investors in our country stock market from 2015 to early 2015. the most fundamental reason is: the real economy profit margin is too low,the hot money had nowhere to go, nations neglected and relaxed financial regulation, Bank credit went into the stock market through a financial product, umbrella trust, P2P finance and other forms, the Banks' capital is bedding bag in high. In addition to the error of the CSRC policies and internal borers, also some short of foreign funds. through the figure and table below shows three "crash". 


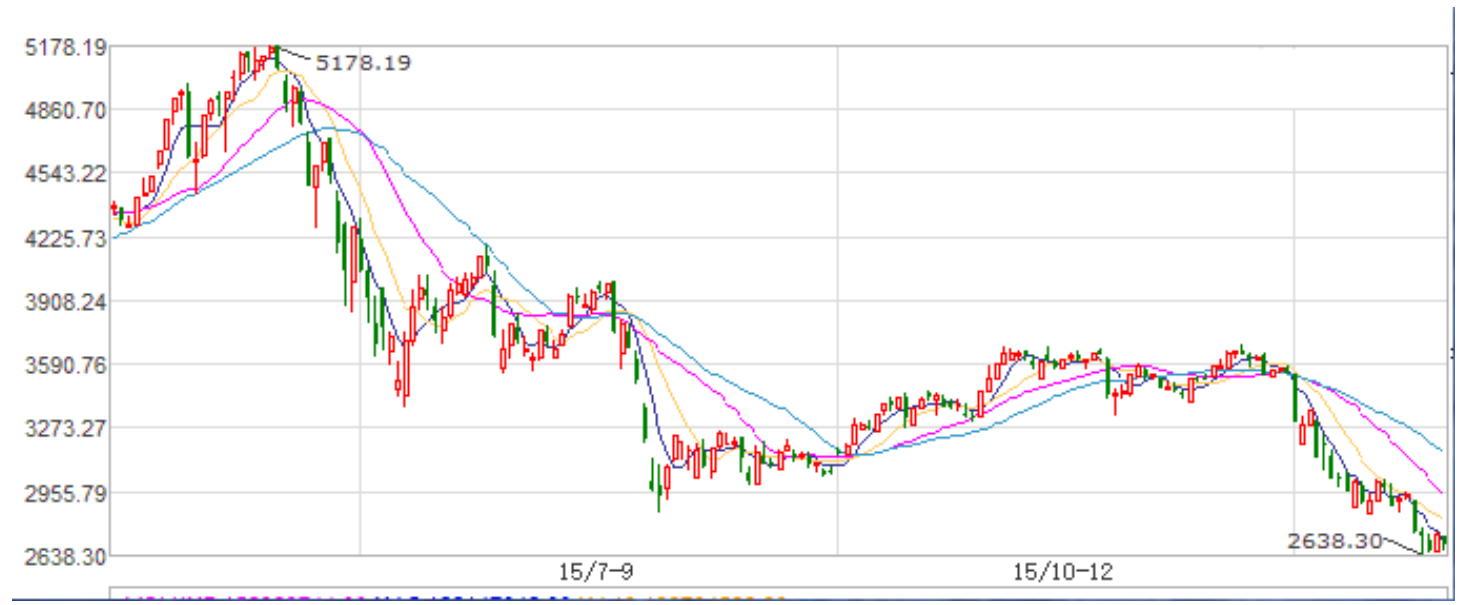

Fig. 1 The Shanghai composite index charts

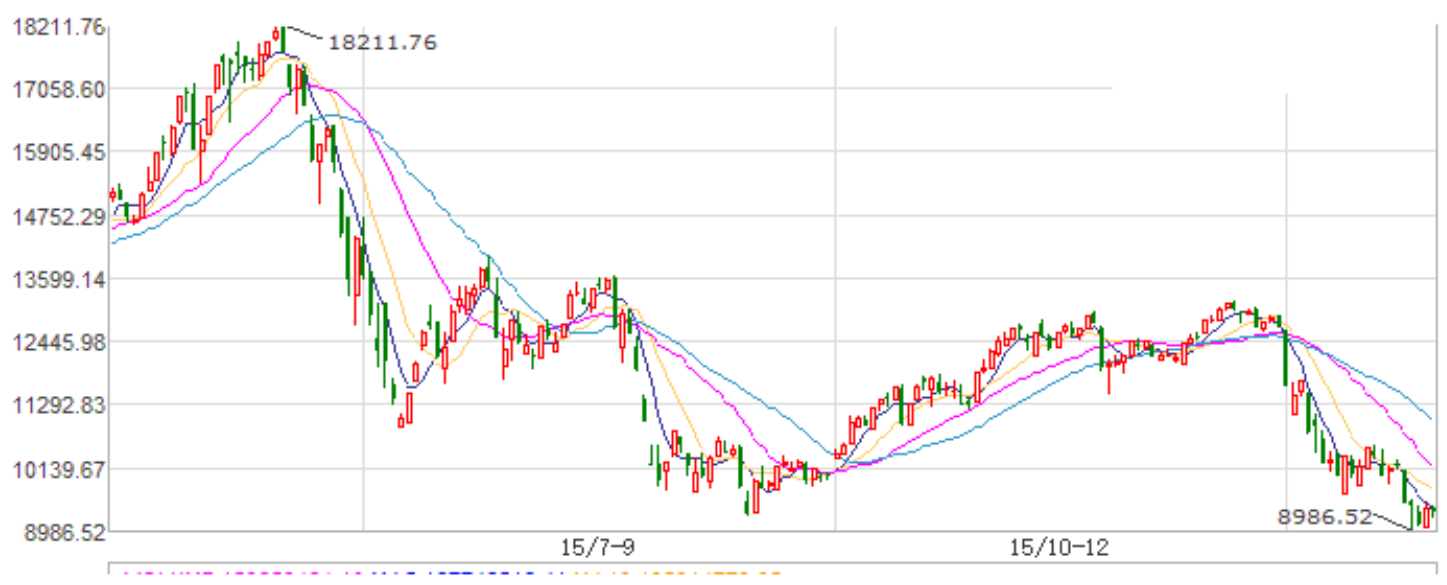

Fig. 2 Shenzhen Component Index charts

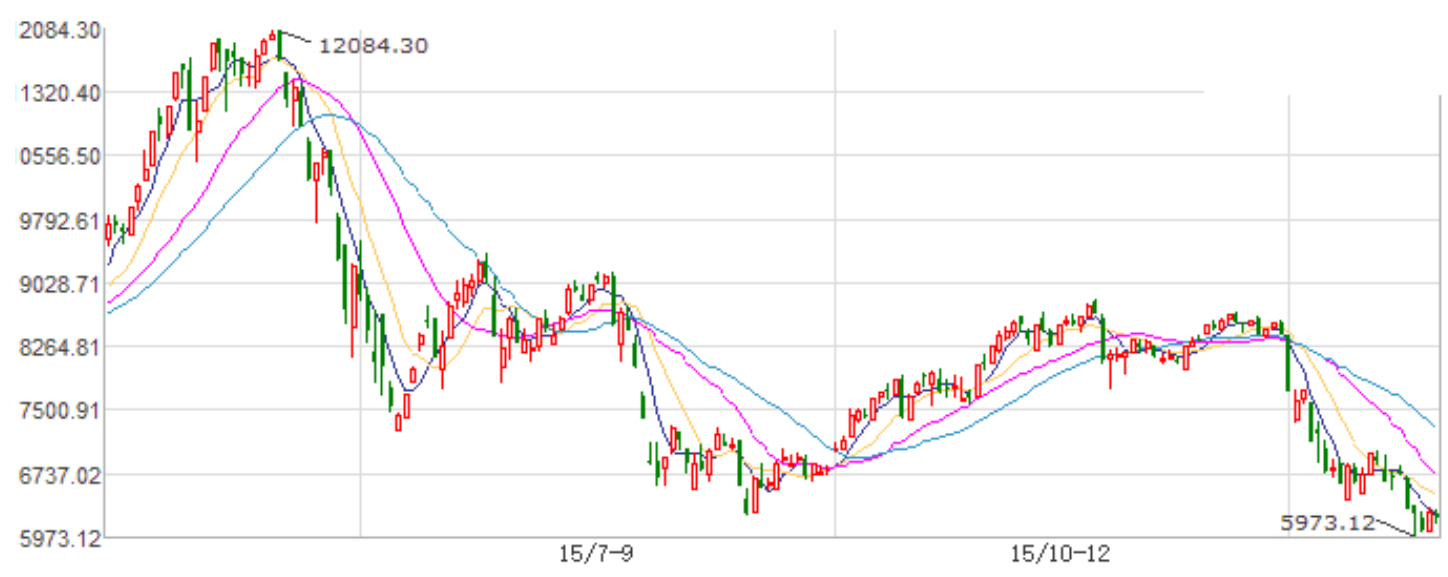

Fig. 3 Shenzhen Small \& Medium Enterprise Board Index charts 


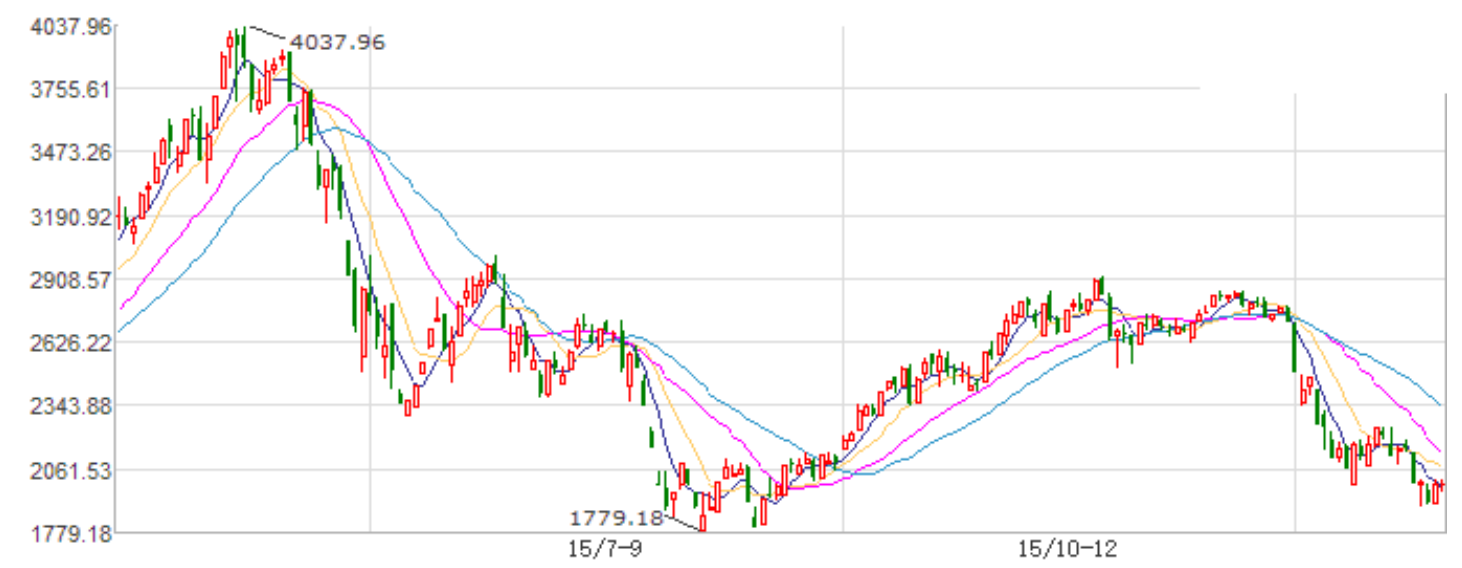

Fig. 4 the growth enterprise index of Shenzhen charts

Table 1 crash index contrast table from 2015 to 2016

\begin{tabular}{|c|c|c|c|c|}
\hline Drop & $\begin{array}{l}2015 \text { Disaster } 1.0 \\
\text { (2015.6. 5-7.9) }\end{array}$ & $\begin{array}{l}201 \text { Disaster } 2.0 \\
(2015.7 .24-9.15)\end{array}$ & $\begin{array}{l}2015 \text { Disaster } 3.0 \\
(2015.11 .26-1.27)\end{array}$ & $\begin{array}{l}\text { The total } \\
\text { losses }\end{array}$ \\
\hline $\begin{array}{l}\text { Shanghaicomposite } \\
\text { index }\end{array}$ & $\begin{array}{ll}5176.8 & (0615) \\
3373.54 & (0709)\end{array}$ & $\begin{array}{ll}4184.15 & (0724) \\
2850.71 & (0826)\end{array}$ & $\begin{array}{ll}3684.57 & (1223) \\
2638.3 & (0127)\end{array}$ & $118.96 \%$ \\
\hline $\begin{array}{l}\text { Shenzhen } \\
\text { Component Index }\end{array}$ & $\begin{array}{l}18211.76 \quad(0615) \\
10850.38 \quad(708)\end{array}$ & $\begin{array}{l}13970.84(0724) \\
9259.65 \quad(0915)\end{array}$ & $\begin{array}{ll}13187.05 & (1223) \\
8986.52 & (0127)\end{array}$ & $102.66 \%$ \\
\hline $\begin{array}{l}\text { SMEs composite } \\
\text { index }\end{array}$ & $\begin{array}{ll}12084.3 & (0612) \\
7242.35 & (0708)\end{array}$ & $\begin{array}{ll}9392.15 & (0724) \\
6219.38 & (0915)\end{array}$ & $\begin{array}{ll}8814.77 \quad(1126) \\
5973.12 \quad(0127)\end{array}$ & $102.31 \%$ \\
\hline $\begin{array}{l}\text { the growth } \\
\text { enterprise index }\end{array}$ & $\begin{array}{ll}4037.96 & (0605) \\
& \\
2304.76 & (0708)\end{array}$ & $\begin{array}{ll}3014.18 & (0724) \\
1779.18 & (0902)\end{array}$ & $\begin{array}{ll}2915.95 & (1126) \\
1888.25 & (0127)\end{array}$ & $113.85 \%$ \\
\hline
\end{tabular}

Table2 crash fell by contrast table from 2015 to 2016

\begin{tabular}{|c|c|c|c|c|}
\hline Index & $\begin{array}{l}2015 \text { Disaster } 1.0 \\
\text { (2015.6. 5-7.9) }\end{array}$ & $\begin{array}{l}2015 \text { Disaster } 2.0 \\
\text { (2015.7.24-9.15) }\end{array}$ & $\begin{array}{l}2015 \text { Disaster } 3.0 \\
\text { (2015.11.26-1.27) }\end{array}$ & $\begin{array}{l}\text { The total } \\
\text { losses }\end{array}$ \\
\hline $\begin{array}{l}\text { Shanghaicomposite } \\
\text { index }\end{array}$ & $53.45 \%$ & $46.78 \%$ & $39.66 \%$ & $118.96 \%$ \\
\hline $\begin{array}{l}\text { Shenzhen Component } \\
\text { Index }\end{array}$ & $67.84 \%$ & $50.88 \%$ & $46.74 \%$ & $102.66 \%$ \\
\hline SMEs composite index & $66.86 \%$ & $51.01 \%$ & $47.57 \%$ & $102.31 \%$ \\
\hline $\begin{array}{l}\text { the growth enterprise } \\
\text { index }\end{array}$ & $75.20 \%$ & $69.41 \%$ & $54.43 \%$ & $113.85 \%$ \\
\hline
\end{tabular}


Our financial system is still many deficiencies and vulnerabilities while China as the world's second largest economy, these contradictions lead up to the crash. Once the stock market crash, the direct impact is: Shareholder losses, consumption has fallen dramatically, a tightening consumption will further accelerate industrial depression under the condition of stimulating domestic and demand is very difficult to be broken in the current. at the same time, a large number of investment funds in the stock market, including savings, insurance, pension fund, their huge loss will lead to the direct consequences of tight liquidity, banks would tighten monetary policy, the companies which need to fund cannot get loans, enterprise will appear failures, there are lots of unemployment on society. in addition to the direct impact on the economy, it is more terrible that destroyed national confidence , will surely lead to boiling, directly affect the social stability. in this case, the domestic enterprises with foreign investment will accelerate the evacuation, domestic dignitaries, traders, vested interests will compete to sell assets, real estate, property, and their cash will be transferred abroad. it brought collapse by the sell-off in the real estate industry, housing slump, buyers can choose default, then the bank will appear a large area of bad debts. Some little bank that is unable to pay would forced to close, the RMB exchange rate has plummeted, at this point, the financial crisis broke out thoroughly. How terrible the prospect is!

\section{The "political" strategy response to "Currency war" in he stock market}

More than 30 years of reform and opening up, China's development has been the world's attention, china has become one of the most influential country in the world today. the United States can obtain the biggest economic benefits through the style of the "currency war", but can't use war means to grab the biggest economic benefits.

In 2015, the Chinese took a pragmatic and effective response measures in the "currency war", in addition, I think the key is to strengthen political consciousness in the stock market regulation, specifically with the following:

\subsection{To strengthen political consciousness in the stock market regulation}

Regulators in the stock market regulation must strengthen political consciousness, to maintain the political conscious and determined. this is the needs to maintain he overall situation of the reform, development and stability, also is our fundamental guarantee to improve the quality of the work. The discipline is the red line and bottom line. leaders should take the lead in strengthen ing political consciousness, stand firm, clear-cut stand on the question of right versus wrong.

\subsection{Establish accountability mechanism}

We must establish the supervision system of accountability in the stock market for the related supervisors fault and the fault of responsibility, what behavior belongs to the illegal act, shall bear the administrative responsibility, should by which administrative punishment, should have some form of specification file or provision to make clear a regulation.

\subsection{To a reasonable understanding of financial innovation}

In recent years, in the mainland stock market has been launched many innovative financial tools, such as stock index futures, securities margin trading, etc, and risk management consciousness was obviously relaxed, the development of financial derivatives market, increasing the vulnerability of 
the global financial system. compared with traditional financial products, financial derivatives have strong permeability and great leverage, more lethal. financial derivatives with the risk of hidden dangers is becoming more and more big, until detonated[7].three crash wake-up us again and again, we have to nip in the bud, especially need to strengthen risk monitoring to the investment of financial derivatives. We should adhere to the principle of "advance carefully and sustainable development" in the financial markets.

\subsection{To strengthen the supervision of the quality and information disclosure of listed companies}

Capital optimization of listed companies is the precondition of social resource allocation optimization, the function of the optimal allocation of resources of the stock market are closely related with the quality and authenticity of the information disclosure of listed companies. If there is the poor quality of listed companies, the false information disclosure, this feature would be lost, it will cause the stock market to fall for a casino. the reality and potential value of a stock of a listed company is reality and the future contribution to society and shareholders, if regulation is laxed, false information will lead to collapse of the value discovery function of the stock market. so we should strengthen the supervision of the quality and information disclosure of listed companies.

All in all, as a "currency war" battlefield, market supervision responsibility is significant. America is playing the "currency war", while advocate the so-called new liberalism, they advocate the purpose of the new liberalism, the essence is to change the basic economic system of China weaken the control of the national economy of the Chinese government. So, political consciousness in our financial regulation is absolutely important and cannot be ignored.

\section{References}

[1] Information on http://baike.so.com/doc/4369842-4575701.html. The stock market.

[2] Information on http:// www.baike.com.

[3] Information on http://finance.sina.com.cn/hy/20071016/18124066614.shtml. the ten characteristics of global financial structure in the new century. 2007,10.

[4] Information on http://baike.so.com/doc/4959833-5181821.html. currency war.

[5] Information on http:// wap.eastmoney.com.

[6] Information on http://www.cankaoxiaoxi.com/. 2015,12.

[7] Information on http://www.p5w.net/news/xwpl/200801/t1468038.htm. Guard against the negative impact of financial innovation. 2008,1. 